\title{
Optimization of Sulfur Soaking Water on Mechanical Properties and Physical Properties of Woven Petung Bamboo (Dendrocalamus asper Backer ex Heyne) Strips
}

\author{
Rahab Martini Bako ${ }^{I}$, Farid Sariman ${ }^{1}$, Christian Wely Wullur ${ }^{1}$, \\ Klemens Alrin Rahangmetan ${ }^{1 *}$, Cipto Cipto ${ }^{1}$, Wahyu Widodo ${ }^{2}$, and Peeyush Soni ${ }^{3}$ \\ ${ }^{1}$ Mechanical Engineering, Faculty of Engineering, Musamus University, Kamizaun Mopah Lama, \\ Merauke 99611, Papua, Indonesia \\ ${ }^{2}$ Unit of Data Processing, Faculty of Agriculture and Animal Science, University Muhammadiyah \\ Malang, Jl. Raya Tlogomas 246, Malang 65144, East Java, Indonesia. \\ ${ }^{3}$ Department of Agricultural and Food Engineering, Indian Institute of Technology Kharagpur, \\ Kharagpur, West Bengal 721302, India
}

\begin{abstract}
There are about 60 species of bamboo belonging to family gramineae found in Indonesia, which is one of them is Petung bamboo (Dendrocalamus asper). Bamboo has the potential to produce environmentally friendly engineering materials. The strength and durability of the material can be increased through the immersion process using chemical or natural solutions, such as sulphur water because it is known to contain carbon elements high enough to support strength increase. The research was started by making thick bamboo slats $1 \mathrm{~mm}$ thick, $250 \mathrm{~mm}$ long, $10 \mathrm{~mm}$ wide, and then woven in plain shapes of $250 \mathrm{~mm} \times 250 \mathrm{~mm}$, then dried at $110{ }^{\circ} \mathrm{C}$ for $60 \mathrm{~min}$ then immersed in sulfur water. For tensile test using the ASTM D638-02 standart, ASTM D790-02 bending test, ASTM D5942-96 impact test. The test results show the tensile strength increased $89.17 \%$, bending strength increased $59.90 \%$ and impact strength increased $1.59 \%$. The highest value of the mechanical test results occurred in sample $1 \mathrm{AB} 3$, while the lowest mechanical test value occurred in $1 \mathrm{TP}$ sample. The microstructure of the $1 \mathrm{TP}$ sample shows a pointed and smooth fracture shape while the sample $1 \mathrm{AB} 3$ has an increasingly blunt fracture shape with fine threads.
\end{abstract}

Key words: Bamboo strips, mechanical strength, microstructure, sulfur water

\section{Introduction}

The growth rate of bamboo plants is fast enough so that their availability can be met quickly as well and can absorb carbon dioxide quickly so that it can reduce air pollution, in addition to the large enough carbon content in the wood can increase strength. The strength

\footnotetext{
* Corresponding author: krahangmetan@unmus.ac.id
} 
of bamboo in the form of strips is stronger than in the form of whole bamboo. The use of bamboo which has artistic value is a product of strips that are usually made of woven for various kinds of household items, walls, and furniture. Polymer composites reinforced with woven bamboo are materials consisting of layers of woven bamboo strips that are joined together with resin, so that the use of bamboo from the strip needs to be optimized [1].

Cellulose fibers contained in bamboo provide maximum flexural tensile strength and hardness in certain directions [2]. Lignin is a component of cell walls that is difficult to break down by organisms that destroy bamboo. Bamboo is one of the abundant and interesting natural fibers to be studied. Table 1 shows the composition of bamboo compositions.

Table 1. The composition of bamboo composition

\begin{tabular}{lccccc}
\hline Type of Bamboo & $\begin{array}{c}\text { Holocellulose } \\
(\boldsymbol{\%})\end{array}$ & $\begin{array}{c}\text { Lignin } \\
(\boldsymbol{\%})\end{array}$ & $\begin{array}{c}\text { Fiber Cell } \\
(\boldsymbol{\mu m})\end{array}$ & $\begin{array}{c}\text { Pore Cell } \\
(\boldsymbol{\%})\end{array}$ & $\begin{array}{c}\text { Alcohol Solution } \\
\text { Benzene }(\boldsymbol{\%})\end{array}$ \\
\hline Petung & 73.63 & 27.37 & 0.90 & 12.58 & 4.10 \\
Sero & 71.96 & 26.18 & 0.80 & 14.96 & 3.43 \\
Tui & 72.77 & 26.05 & 0.77 & 13.23 & 3.49 \\
\hline
\end{tabular}

The alpha cellulose content of Tui bamboo is relatively more than that of Petung bamboo and Sero bamboo so that it can be predicted that Tui bamboo will experience greater damage by termites [3]. Petung bamboo mechanical properties for flexural strength of 134.972 MPa, tensile strength of $228 \mathrm{MPa}$ parallel fibers, compressive strength of 49.206 $\mathrm{MPa}$ parallel fibers, compressive strength of perpendicular fibers of $24.185 \mathrm{MPa}$, shear strength of 9.505 MPa in parallel, and flexural modulus of elasticity of $12888.477 \mathrm{MPa}$ [4].

Strength and mapping of a material can be increased through a preservation process such as immersion treatment using elements or chemical solutions but also using natural elements or solutions such as sulfur water, sea water, rice water, turmeric juice, tea leaf extract, and so on. One of the elements or solutions that are underutilized is sulfur. It is also known to be an important element in life. About $0.25 \%$ of the total body weight of humans is sulfur. This is most concentrated in keratin, which makes hair, nails, and skin strong. This is known as the "mineral of natural beauty" because the body needs it to produce collagen, which makes the skin elastic and young-looking. So that sulfur water is used as a bath to treat skin disorders, help protect the body from environmental toxins, and people who experience arthritis can find pain relief by bathing in hot sulfur water.

\section{Research methods}

\subsection{Ingredients}

The natural fiber is very widely used in the automotive and construction industries. In addition to being environmentally friendly and economically valuable, another advantage of natural fiber composites is that they are light in weight and also easily available due to their abundant availability [5]. The natural fibers used are Petung bamboo (Dendrocalamus asper Backer ex Heyne) and also sulfur water in Lembang Tokesan, Sangalla District, Tana Toraja Regency, South Sulawesi Province. Petung bamboo is soaked using sulfur water, which aims to increase mechanical strength. Petung bamboo soaked using sulfur water, which aims to increase mechanical strength. Data from laboratory analysis of sulfur water used contained carbon (C) as much as $78.0 \mathrm{mg} \mathrm{L}^{-1}$, followed by sulfur as $\mathrm{SO}_{4}$ as much as $39.101 \mathrm{mg} \mathrm{L}^{-1}$, then silica as $\mathrm{SiO}_{2}$ as much as $22.03 \mathrm{mg} \mathrm{L}^{-1}$ and sulfur as $\mathrm{H}_{2} \mathrm{~S}$ as much as $0.009 \mathrm{mg} \mathrm{L}^{-1}$. Bamboo species of Petung and also hot sulfur water used in this study were 
taken at Lembang Tokesan, Sangalla 'District, Tana Toraja Regency, South Sulawesi Province.

The epoxy matrix used consisted of Epoxy resin A (Bisphenol A-epichlorohydrin) and Epoxy hardener B (Polyaminoamide) with a mixture ratio of $60 \%: 40 \%$ of the total volume of composite molds which had a size of $250 \mathrm{~mm} \times 250 \mathrm{~mm} \times 4 \mathrm{~mm}$.

\subsection{Tools}

The tool used as a composite print is made of steel measuring $250 \mathrm{~mm} \times 250 \mathrm{~mm}$ and also uses supporting tools such as a $500 \mathrm{~mL}$ measuring cup, $3 \mathrm{~mL}$ syringe (for measuring catalysts), knives, spoons, scissors, brushes, space thermometers, water thermometers, calipers, sandpaper, digital scales, spoons, bamboo thinning tools and electric ovens. While the tensile test used is the Go Tech Universal Testing Machine, Model KT-7010A2, capacity $1000 \mathrm{~kg}$, the production of Kao Tieh Machinery industrial CO., LTD, in 1995. At the time of the tensile test the tensile testing machine speed is $4 \mathrm{~mm} \mathrm{~min}^{-1}$.

\subsection{Testing process}

Availability and utilization/function of abundant natural wealth can be used as composite materials using bamboo and sulfur water. The study began with the manufacture of bamboo strips $1 \mathrm{~mm}$ thick, $250 \mathrm{~mm}$ long, $10 \mathrm{~mm}$ wide, and then weaved plain shapes measuring $250 \mathrm{~mm} \times 250 \mathrm{~mm}$. Furthermore, the woven bamboo is dried at $110^{\circ} \mathrm{C}$ for $60 \mathrm{~min}$ then the webbing is soaked in hot sulfur water for $1 \mathrm{~d}, 2 \mathrm{~d}$, and $3 \mathrm{~d}$. After the bamboo webbing is soaked, the next process is composite printing and wait for $6 \mathrm{~h}$ to $8 \mathrm{~h}$ for the results to dry. Then the sample is cut to the size of the specimen for further mechanical testing. The tensile test standard used by ASTM D 638-02, bending test using ASTM D 790-02, and impact test using ASTM D 5942-96. Always weight the sample from after bamboo is woven/before it is dried after it has been dried and after composite. Figure 1 shows the specimens that have been cut according to ASTM for tensile, bending, and impact tests and are ready for mechanical testing.

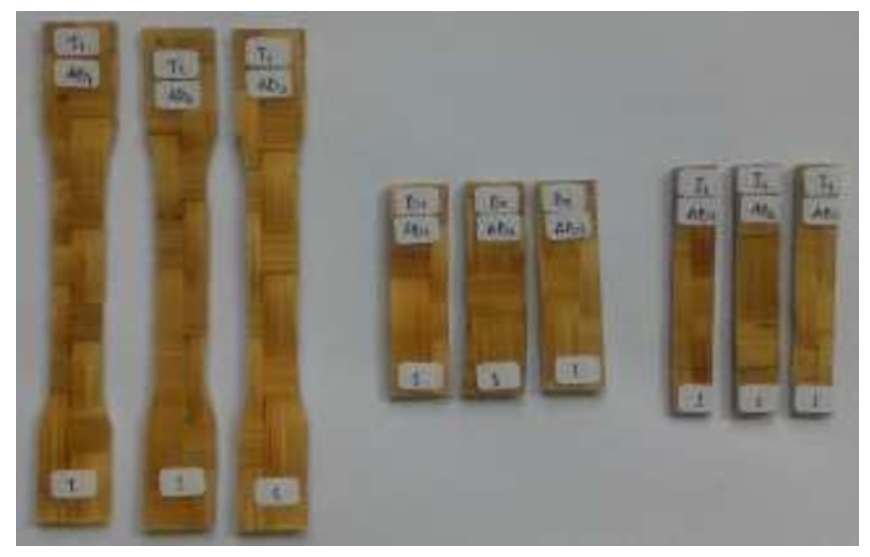

Fig. 1. Tensile, bending and impact test specimens

The mechanical tests carried out in this study were tensile, bending and impact tests. Tensile strength is a test carried out to determine the ability of a material to accept loads without damage. The tensile strength of a material is determined by dividing the maximum force with the initial cross-sectional area before deforming. The tensile strength of a material can be calculated by Equation (1): 


$$
\sigma=\frac{F_{\max }}{A_{o}}
$$

where:

$\sigma \quad$ : Tensile strength of material $\left(\mathrm{kgf} \mathrm{mm}^{-2}\right)$

$F_{\max }$ : Maximum voltage (kgf)

$A_{0} \quad$ : Initial cross-sectional area $\left(\mathrm{mm}^{2}\right)$

Bending test is a form of testing to determine the quality of a material visually. The bending strength of a material is the strength of the material to withstand compressive loads from the outside. The value of the poisson ratio has an effect on the bending test. From the bending test a linear distribution of direct stress will be produced which varies with thickness and strain on the other surface [6]. The bending stress on the material can be calculated by the Equation (2):

$$
\sigma f=\frac{3 \times P \times L}{2 \times b \times d^{2}}
$$

where:

$P: \operatorname{load}(\mathrm{N})$

$L:$ Support Span (mm)

$b$ : width of the test object $(\mathrm{mm})$

$d$ : thickness of the test object (mm)

The toughness of a material is the ability of the material to accept impact loads as measured by the amount of energy needed to break the test rod with a swing hammer. To find out the toughness value of a material an impact test must be carried out, the amount of power to break the test rod can be calculated by the Equation (3):

$$
W=m \times g \times R(\cos \beta-\cos \alpha)
$$

where:

$W$ : Broken energy $(\mathrm{J})$

$m$ : Weight of pendulum $(\mathrm{kg})$

$g$ : Gravity acceleration $\left(\mathrm{m} \mathrm{s}^{-2}\right)$

$R$ : Distance of pendulum to center of rotation $(\mathrm{mm})$

$\beta$ : Pendulum angle after hitting a test object $\left(^{\circ}\right)$

$\alpha$ : Pendulum angle without test object $\left({ }^{\circ}\right)$

As for the impact strength using the Equation (4):

$$
a=\frac{W}{d \times b}
$$

where:

$a$ : Impact strength $\left(\mathrm{J} \mathrm{mm}^{-2}\right)$

$b$ : Specimen width $(\mathrm{mm})$

$d$ : Thickness of specimen (mm)

$W$ : Energy absorbed by specimens (J) 


\section{Results and discussion}

\subsection{Mechanical test results}

Please composite test results of woven Petung bamboo treatment of soaking sulfur water 1 ply for $0 \mathrm{~d}, 1 \mathrm{~d}, 2 \mathrm{~d}$ and $3 \mathrm{~d}$. With the sample code information as follows 1 ply without treatment (1 TP), 1 ply soaking sulfur water for $1 \mathrm{~d}$ (1 AB1), 1 ply soaking sulfur water for $2 \mathrm{~d}(1 \mathrm{AB} 2)$ and 1 ply soaking sulfur water during $3 \mathrm{~d}$ (1 AB3).

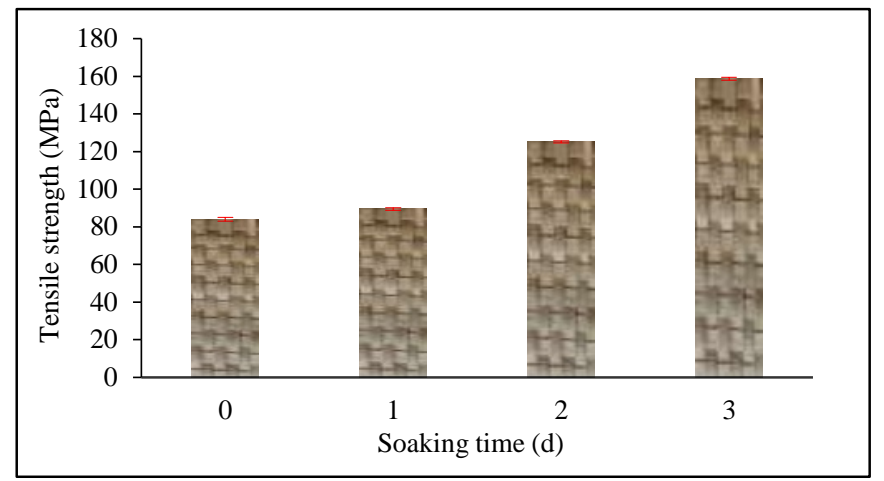

Fig. 2. Relationship between length of immersion time tensile strength 1 ply soaking sulfur water

Figure 2 shows the relationship between the time of immersion on the tensile strength of composite samples of woven Petung bamboo with the treatment of soaking sulfur water with 1 ply for $0 \mathrm{~d}, 1 \mathrm{~d}, 2 \mathrm{~d}$ and $3 \mathrm{~d}$. From the results of this study, the lowest tensile strength was obtained in the sample of $0 \mathrm{~d}(1 \mathrm{TP})$, which was $84.04 \mathrm{MPa} \pm 0.87 \mathrm{MPa}$, while the highest tensile strength occurred in samples with immersion for $3 \mathrm{~d}$ (1 AB3) which was $159.02 \mathrm{MPa} \pm 0.47 \mathrm{MPa}$.

Research on the tensile strength of Petung bamboo is said, the tensile strength of BRP is influenced by the type of bamboo and the variety of fibers. The results of the research show that bamboo plaited woven has a tensile strength of $111.25 \mathrm{MPa}$ while that which is not woven is $94.25 \mathrm{MPa}$. While research on chemicals using bamboo fiber Petung, borax and boric acid and distilled water as a solvent shows that preservative chemicals can increase the tensile strength of bamboo [7].

The effect of preservative chemicals on the tensile strength of Petung bamboo produces a non-preservative skinless Petung bamboo of $88.52 \mathrm{MPa}$, skinless Petung bamboo with borax preservative and soaked for $72 \mathrm{MPa}$ of $90.62 \mathrm{MPa}$. Whereas skinless Petung bamboo with boric acid is $122.1 \mathrm{MPa}$ and skinless Petung bamboo with borax $60 \%$ boric acid is 149.37 MPa [8].

Some of the supporting studies above show that Petung bamboo woven later given chemical treatment can increase composite tensile strength. It also shows that the absorption of carbon elements contained in sulfur water during the immersion treatment has occurred. Because carbon is known to increase strength. The length of time the immersion treatment can also affect the composite tensile strength it is seen that the material that is still in the form of woven bamboo has not reached optimal absorption/has not reached its saturation point so that the resulting strength is still increasing. 


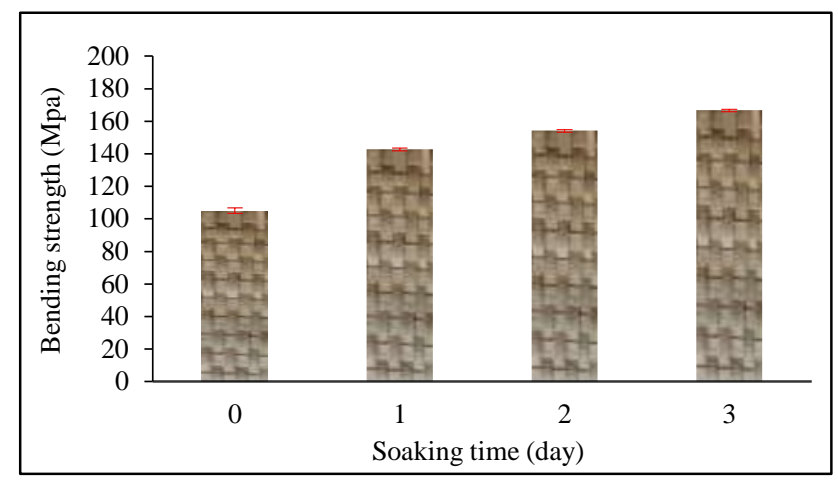

Fig. 3. Relationship between soaking time and bending strength the treatment of 1 ply sulfur water

Figure 3 shows the lowest bending strength value occurred in the sample of $0 \mathrm{~d}$ (1 TP) which is $104.38 \mathrm{MPa} \pm 1.36 \mathrm{MPa}$ while the highest bending strength occurs in samples with $3 \mathrm{~d}$ immersion $(1 \mathrm{AB} 3)$ which is $166.90 \mathrm{MPa} \pm 0.50 \mathrm{MPa}$. The results of the above study are not much different from the influence of borax on the nature and mechanical behavior of Petung bamboo lamination using $5 \%$ borax [9]. As a result of the absorption that occurs during immersion in sulfur water and also woven fibers or braids also increase the flexural strength.

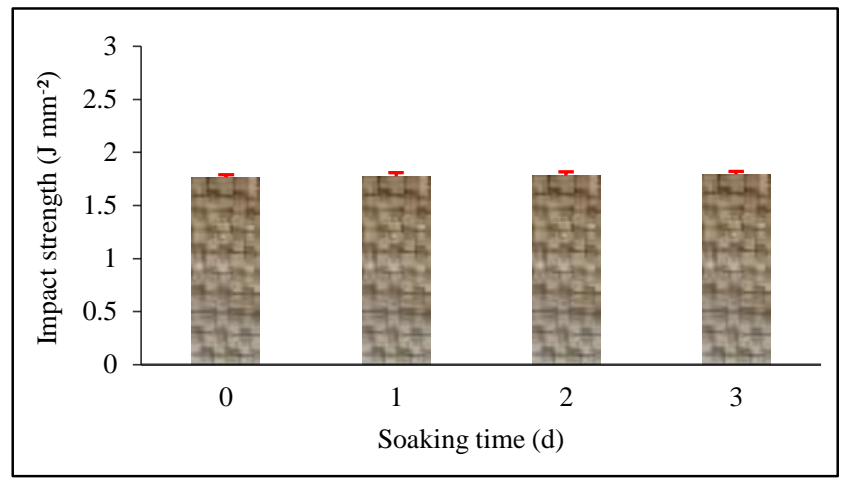

Fig. 4. Relationship between immersion time to impact strength treatment of soaking sulfur water 1 ply

Figure 4 shows the lowest impact strength value occurs in the sample of 0 day (1 TP) which is equal to $1.77 \mathrm{~J} \mathrm{~mm}^{-2} \pm 0.03 \mathrm{~J} \mathrm{~mm}^{-2}$ while the highest impact strength occurs in samples with $3 \mathrm{~d}$ immersion ( $1 \mathrm{AB} 3$ ) which is equal to $1.79 \mathrm{~J} \mathrm{~mm}^{-2} \pm 0.03 \mathrm{~J} \mathrm{~mm}^{-2}$. The above research is in line with the manufacture of banana frond fiber composites using $\mathrm{NaOH}$ having the highest energy and impact prices at the $60 \%$ fiber volume fraction and $40 \%$ matrix having an energy of $1.7998 \mathrm{~L}$ and an impact price of $0.01798 \mathrm{~J} \mathrm{~mm}^{-2}$. It can be concluded that fiber with $\mathrm{NaOH}$ treatment will increase its mechanical strength [10].

\subsection{Measuring microscope laser test results}

The results of the photo analysis of composite plaited woven bamboo samples of Petung were taken based on the variation of soaking time with each 1 ply good without treatment and also the soaking treatment in sulfur water. Micro photo taking is done morphologically by cutting composite test specimens measuring $0.5 \mathrm{~cm} \times 0.5 \mathrm{~cm}$ using a 3D Laser Measuring Microscope at 400 times magnification.

Figure 5(a) is a non-treatment 1 ply composite micro-photo showing the fracture of the material looks brittle because of the presence of a very sharp/pointed and smooth fiber fracture with neat matrix cracks and vertical crack direction towards the direction of the 
fiber. Whereas Figure 5(b), Figure 5(c), and Figure 5(d) is a composite photo of 1 ply composite fault with the treatment of sulfur water for $1 \mathrm{~d}, 2 \mathrm{~d}$ and $3 \mathrm{~d}$. Showing the fracture of the non-brittle material due to the shape of the fiber fracture that is not too sharp/blunt and looks more and more appearance/emergence of thread or fine fiber with the shape of the fracture matrix still looks neat and vertical crack direction towards the direction of the fiber.

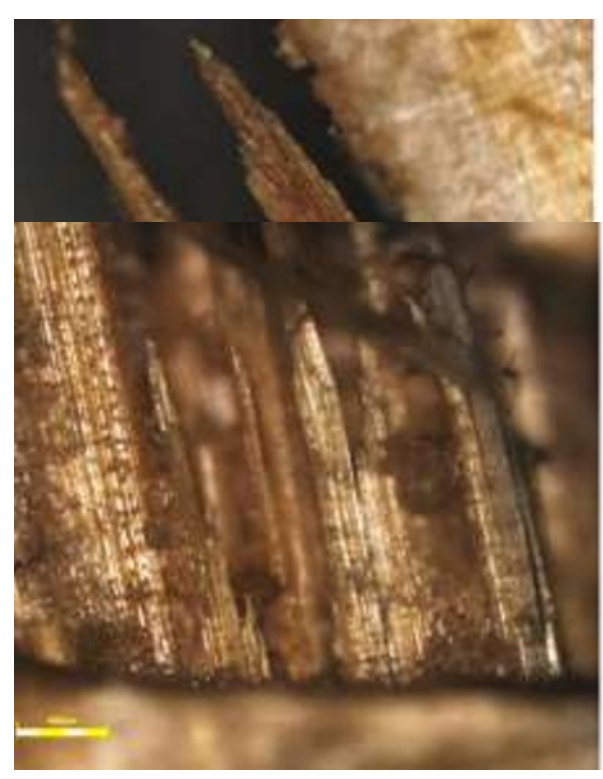

(a)

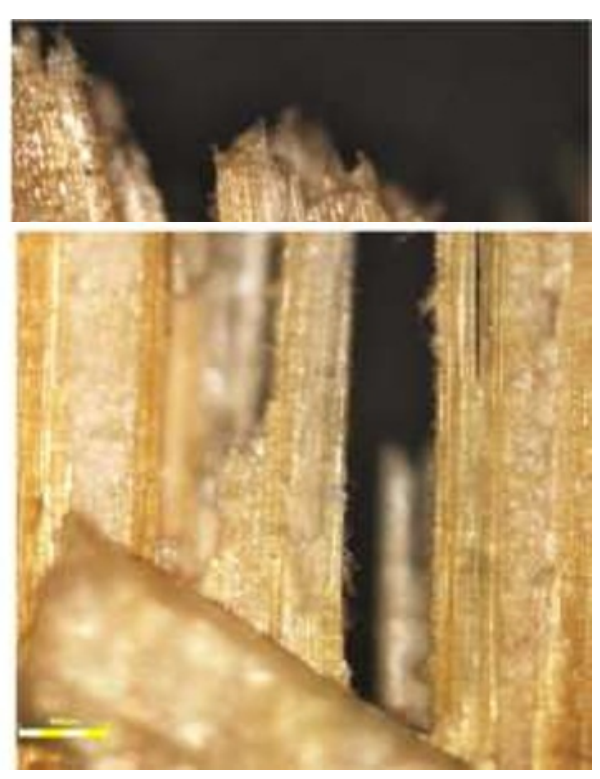

(b)

(d)

Fig. 5. Composite micro photo 1 ply woven Petung bamboo (a) Without treatment, (b) Soaking $1 \mathrm{~d}$ of sulfur water, (c) Soaking sulfur water for $2 \mathrm{~d}$ and (d) Soaking sulfur water for $3 \mathrm{~d}$

\section{Conclusion}

The results of the study 'the effect of water treatment of soaking sulfur woven Petung Bamboo (Dendrocalamus asper) on the mechanical strength of bematric composite-epoxy resin' can be concluded that, the effect of the botanical Petung immersion treatment using sulfur water obtained the highest tensile strength in the $3 \mathrm{~d}$ sample (1 AB3) which was 159.02 $\mathrm{MPa} \pm 0.47 \mathrm{MPa}$. The highest bending strength value occurred in the $3 \mathrm{~d}$ sample (1 AB3) which was $166.90 \mathrm{MPa} \pm 0.50 \mathrm{MPa}$. While the impact test obtained the highest strength value occurred in the sample $3 \mathrm{~d}(1 \mathrm{AB} 3)$ which is equal to $1.79 \mathrm{~J} \mathrm{~mm}^{-2} \pm 0.03 \mathrm{~J}$ $\mathrm{mm}^{-2}$. Petung bamboo which is woven or braided fiber then given chemical treatment can increase the composite mechanical strength. The length of time the immersion treatment can also affect the composite mechanical strength. Micro acyl photo shows the occurrence of fracture changes in which the sample without immersion is sharp and smooth/does not show the presence of fiber threads, while the soaking samples of woven Petung bamboo with hot sulfur water are slightly blunt and the threads appear on the fibers. So that there is a greater effort to maintain strength before finally breaking up. 


\section{Suggestion}

From the results of the research obtained several things that were suggested in subsequent studies, including:

i. In the treatment of soaking sulfur water to varying the amount of ply in the composite.

ii. In the treatment of soaking sulfur water in order to increase the estimated immersion time which is not too much different.

\section{References}

1. A.D. Catur, Sinarep, P.D. Setiawan, A. Zainuri, Supriyadi. Dinamika Teknik Mesin, 5,1:32-41(2015). [in Bahasa Indonesia]. https://www.academia.edu/34981305/BENDING_AFTER_IMPACTKOMPOSIT_SA NDWICH_BERPENGUAT_SERAT_BAMBUFIBERGLASS_DENGAN_COREPOLYURETHANE_RIGID_FOAM

2. E.T. Bahtiar, N. Nugroho, S. Surjokusumo, L. Karlinasari, D.S. Nawawi, D.P. Lestari. Pengaruh komponen kimia dan ikatan pembuluh terhadap kekuatan tarik bambu. In : Prosiding Seminar Nasional MAPEKI XVII. R. Hartono, A.H. Iswanto, K.S. Hartini, A. Susilowati, D. Elfiati, Muhdi, et al. (Eds). Bogor: Masyarakat Peneliti Kayu Indonesia (2014). pp. 119-130. [in Bahasa Indonesia]. http://unhas.ac.id/fahutan/data/Prosiding-MAPEKI-17-XVII-Medan.pdf.

3. M. Loiwatu, E. Manuhuwa. AGRITECH, 28,2:76-83(2016). [in Bahasa Indonesia]. https://www.neliti.com/id/publications/99981/komponen-kimia-dan-anatomi-tigajenis-bambu-dari-seram-maluku

4. N.I.S. Hermanto, I. Satyarno, D. Sulistyo, T.A. Prayitno. Dinamika Rekayasa, 10,: 6-13(2014). [in Bahasa Indonesia].

https://media.neliti.com/media/publications/58451-ID-sifat-mekanika-bambu-petunglaminasi.pdf.

5. I.M. Astika, I.P. Lokantara, I.M.G. Karohika. Jurnal Energi dan Manufaktur, 6,2: 115-122(2013). [in Bahasa Indonesia]. https://ojs.unud.ac.id/index.php/jem/article/download/10002/7439.

6. A.P. Irawan, I.W. Sukania. Jurnal Teknik Mesin, 14,2:59-63(2013). [in Bahasa Indonesia]. http://jurnalmesin.petra.ac.id/index.php/mes/article/view/19000

7. A.R. Fattah, H. Ardhyananta, Jurnal Teknik Pomits, 1,1:1-6(2013). [in Bahasa Indonesia]. http://digilib.its.ac.id/public/ITS-paper-32569-2709100057-paper.pdf.

8. A.R. Fattah, K.N.N. Prinindya, H. Ardhyananta. IPTEK, Journal of Proceeding Series, 1:119-124 (2014). http://iptek.its.ac.id/index.php/jps/article/view/580

9. Setyawati, Morisco, T.A. Prayitno. Forum Teknik Sipil, 19,1:1021-1029(2009). [in Bahasa Indonesia]. http://nirmana.petra.ac.id/index.php/cef/article/view/17500/17419.

10. A.E. Purkuncoro. Al-Jazari J. Ilm. Tek. Mesin, 3,2:46-57(2018). [in Bahasa Indonesia]. https://ojs.uniska-bjm.ac.id/index.php/JZR/article/view/1616 